\title{
Coase vs. Pigou in the Petroleum Market
}

\author{
Ju Vinn Chai, Cen Chen, Fabienne Giauque \& Wei Zhu
}

\section{Overview}

Non-renewable resources such as fossil fuels are used extensively in industrial activities and transportation. The carbon emissions generated from those markets are the source of a number of negative externalities such as air pollution, climate change, global warming, and the degradation of ecosystems and natural environments.

To alleviate such externalities societies are usually left with one of two choices. Governments may choose to impose carbon taxes on consumers and heavy-emitting industries. This is effectively a Pigovian tax regulation, which seeks to make market participants internalize the cost of externalities into their private costs in the hope that the net increase in the cost reduces the size of the externality. As an alternative, governments may use the price mechanism of markets rather than a direct tax. This could be called a Coasian approach to curbing the externality. It usually involves creating property rights over the resource that is being polluted (e.g. air or water) and trading rights to access it. A typical example might be the creation of pollution units such as emission permits or carbon allowances. Through the trading of permits among consumers, market forces determine the price of carbon which facilitates an efficient reduction of emissions.

In this paper, we debate the relative merits and problems of both approaches - a Coasian market solution and a Pigovian tax regulation. We consider some concrete applications of both theoretical concepts in doing so. 


\section{Modeling the Externalities}

It is constructive to begin by first illustrating the concept of a negative externality and the source of the resultant inefficiency in a market. We take the petroleum market as a model.

FIGURE 1: THE INEFFICIENCIES ASSOCIATED WITH NEGATIVE EXTERNALITIES

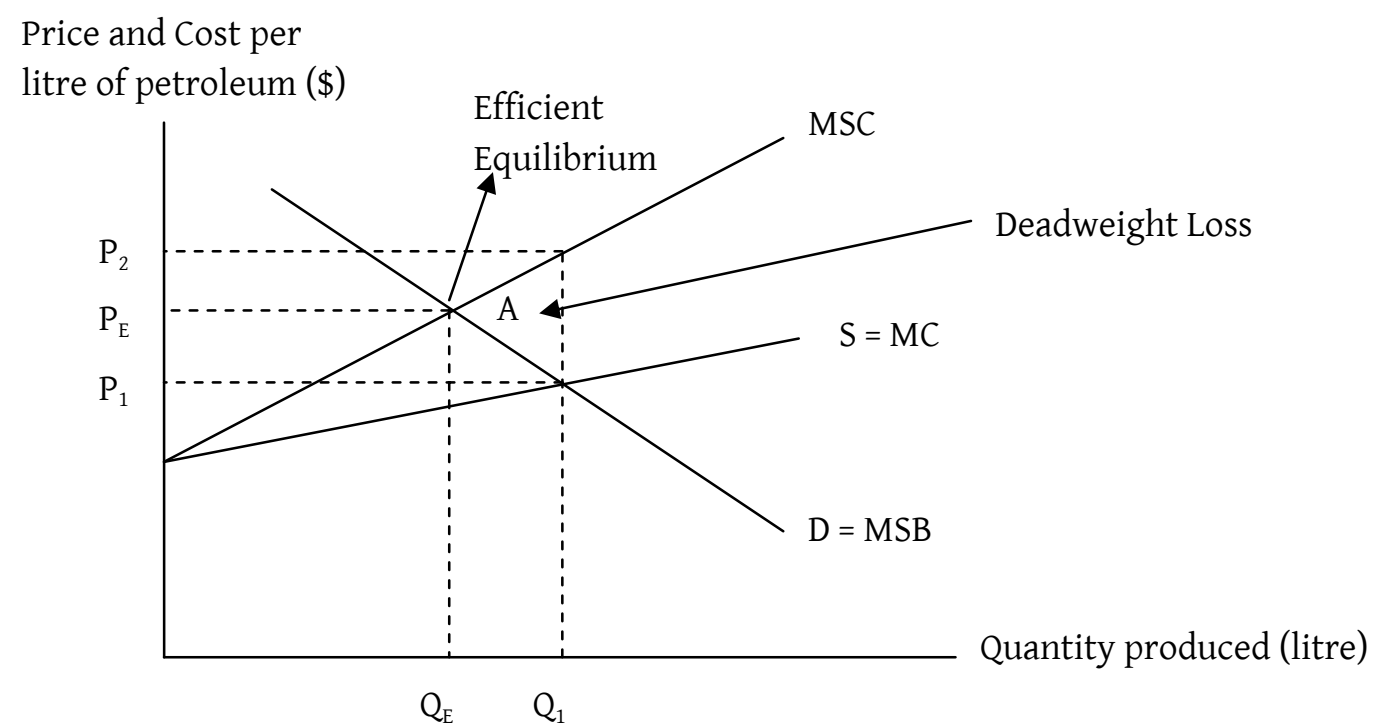

Consider Figure 1. The marginal social benefit curve, denoted MSB, represents demand for petroleum. The supply curve for petroleum producers is represented by the marginal private cost curve, MC. For every marginal litre of petroleum produced and consumed, an additional external cost is borne by the society. This is represented by the marginal social cost, MSC. The marginal external cost borne by members of this society as a result of the petroleum market is derived from the difference between MSC and MC i.e. $\mathrm{P}_{2}-\mathrm{P}_{1}$. Since the market equilibrium is at the intersection of $P_{1}$ and $Q_{1}$, it is inefficient because MSC exceeds MSB. This creates a deadweight loss (area A). Conversely, an efficient market outcome is 
characterized by MSB offsetting MSC in equilibrium. By this definition, the optimal quantity of petroleum that should be produced and consumed by society is hence $\mathrm{Q}_{\mathrm{E}}$.

\section{The Pigovian Tax Regulation}

As an example of how a Pigovian tax intervention would resolve such an externality, let us consider the eco tax implemented by Germany since 1999. We are still using the petroleum market as a backdrop, because the eco tax targets fuel and electricity (Büchs, Duwe \& Bardsley, 2009). The figure below illustrates how the eco tax works.

FIGURE 2: HOW THE GERMAN ECO TAX WORKS

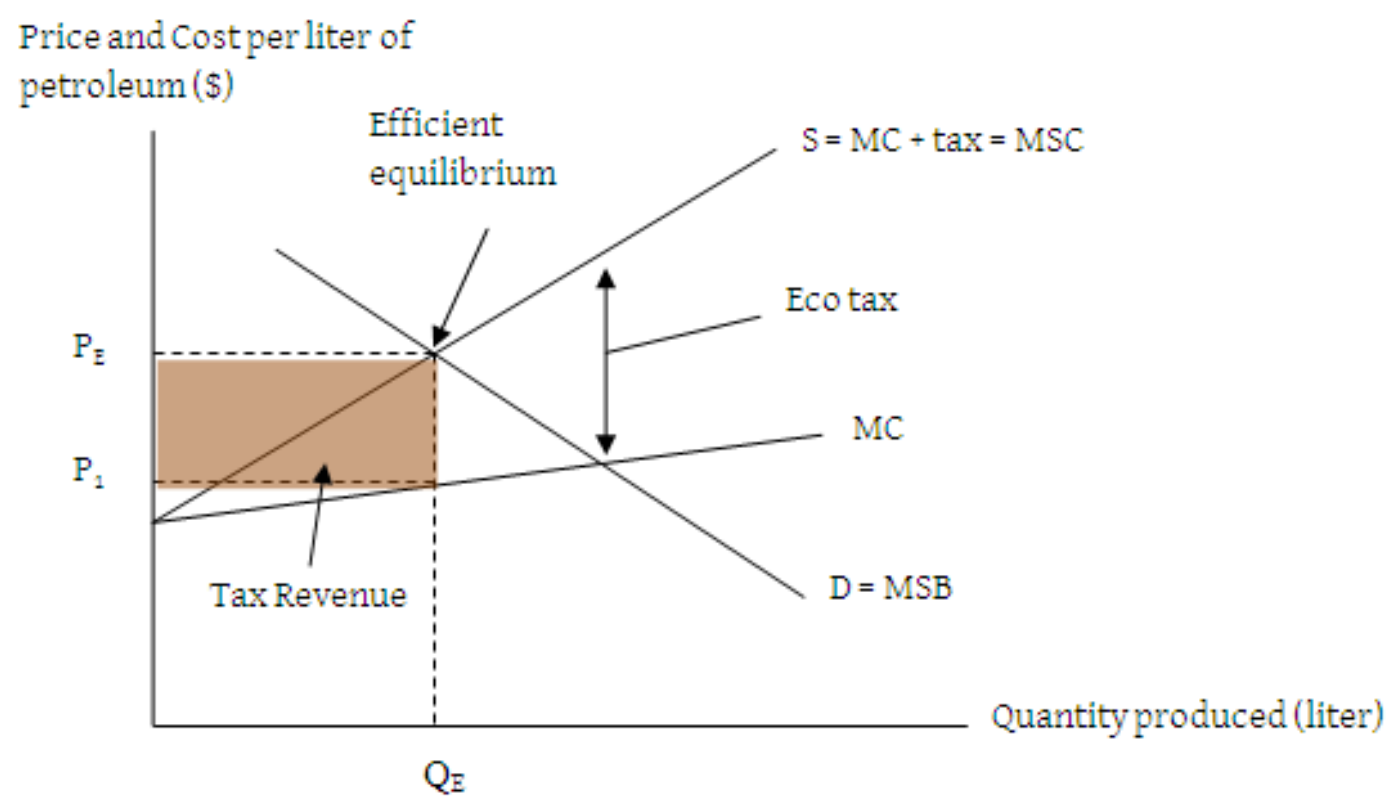


Since the German government wants to influence consumers to curb carbon expenditure, it sets the tax rate equal to the marginal external cost borne by consumers. The MC plus the tax to be paid will thus determine the market supply curve, which is also the MSC. When firms produce petroleum at $\mathrm{Q}_{\mathrm{E}}$, there is efficiency because MSC and MSB are equalized. Consequently, the market price will be set at $\mathrm{P}_{\mathrm{E}}$, and the government collects the tax revenue equivalent to the shaded area in Figure 2.

Proponents of the Pigovian tax solution claim that the tax revenue generated can be redistributed to society or used to reduce other forms of taxation. This was the case for Germany's eco tax, where part of the tax revenue was applied towards reducing social security contributions for senior-citizen pensions (Büchs, Duwe \& Bardsley, 2009). However, the Pigovian approach requires the regulator to possess a high degree of information on the private and social costs in the market. This is potentially problematic in an environment with any degree of uncertainty about the exact amount and nature of the external costs generated by market activity. Furthermore, MSC and MSB must always be equated after the tax has been imposed for it to be an efficient intervention. This implies a dynamic tax rate that varies with carbon emission levels at different times.

If the tax rate is higher than the actual external costs borne by consumers, market participants may object to it. Conversely, if the tax is lower than actual external costs, it would be ineffective in removing the deadweight loss in the market resulting from the emissions externality. The tax is also potentially regressive because poor households usually spend larger proportions of their income on energy than rich households. Thus, an increase in prices for fuel would be asymmetrically burdensome for the poor.

Furthermore, as demand for petroleum has rather low price elasticity, the potential of emission reduction may also be limited by the fact that consumers are often indifferent towards the price changes of essential goods such as fuel. Thus, although tax revenue may be generated in the short run, the long run objective of meeting target levels of emission reduction may not necessarily materialize with a Pigovian tax solution. 


\section{The Coasian Market Solution}

A Coasian market solution involves the creation of property rights to enable the market mechanism to endogenously develop a price. In the case of the petroleum market the establishment of a carbon credit trading market running in parallel is enabled by creating property rights over the atmosphere in the sense that a permit needs to be purchased to emit a fixed amount of carbon. Through establishing property rights, each member of the market is allotted or purchases a certain amount of credits to spend on pollution, and they are then able to trade those units with other participants in the carbon market. The regulator can fix or cap the aggregate number of such permits in circulation thereby controlling the total level of pollution.

The Coasian solution relies on rational consumers and producers pursuing utility maximization and cost minimization objectives. Market participants seek gains from trade and this acts as an incentive for them to change their behavior, eventually reducing externalities. However, given self-interested rational market participants, these gains from trade must be large enough to entice them to change their behavior i.e. the opportunity cost of going green must be lesser than the potential gains.

We shall use the Clean Development Mechanism (CDM), which was established under the Kyoto Protocol, to explain the statement above. Under the CDM, developed countries facilitate greenhouse gas reductions by financing emission-reduction projects in developing countries. In return, developing countries earn certified emission reduction (CER) credits, which are traded and sold in dealings with developed countries (Metcalfe \& Vorhies, 2010). From a rational, utility-maximizing, point of view, the gains from trading these CERs should exceed the costs of implementing the CDM in order to effectively induce consumers to reduce carbon usage.

The property rights attached to pollution units include specifications of the laws of liabilities for damages associated with externalities. Randall (1972) stated that the fullliability rule pertaining to the Coase theorem implies that externalities should not be formed if the affected parties find them objectionable. Hence, acting parties must 
compensate affected parties. In other words, full liability emerges from well-designed and well-enforced property rights to an asset.

Here are some examples to demonstrate the aforementioned statement. Cap-and-trade schemes such as the EU Emissions Trading Scheme and personal carbon allowance scheme function on the premise of placing a cap on carbon emissions, while allocating permits and allowances to consumers to spend within the cap. People holding left-over permits/allowances can thus sell them to heavy polluters at a premium. Note that fullliability is attached to each permit or unit of allowance. Consequently, normal market forces i.e. demand and supply will determine the price of each unit of carbon. As long as the full-liability rule is adhered to, the market will achieve an efficient equilibrium. Figure 3 illustrates the quantity of reduction in emission externalities that should be attained in order to achieve the efficient equilibrium.

FIGURE 3: THE EFFICIENT REDUCTION OF EMISSION EXTERNALITIES

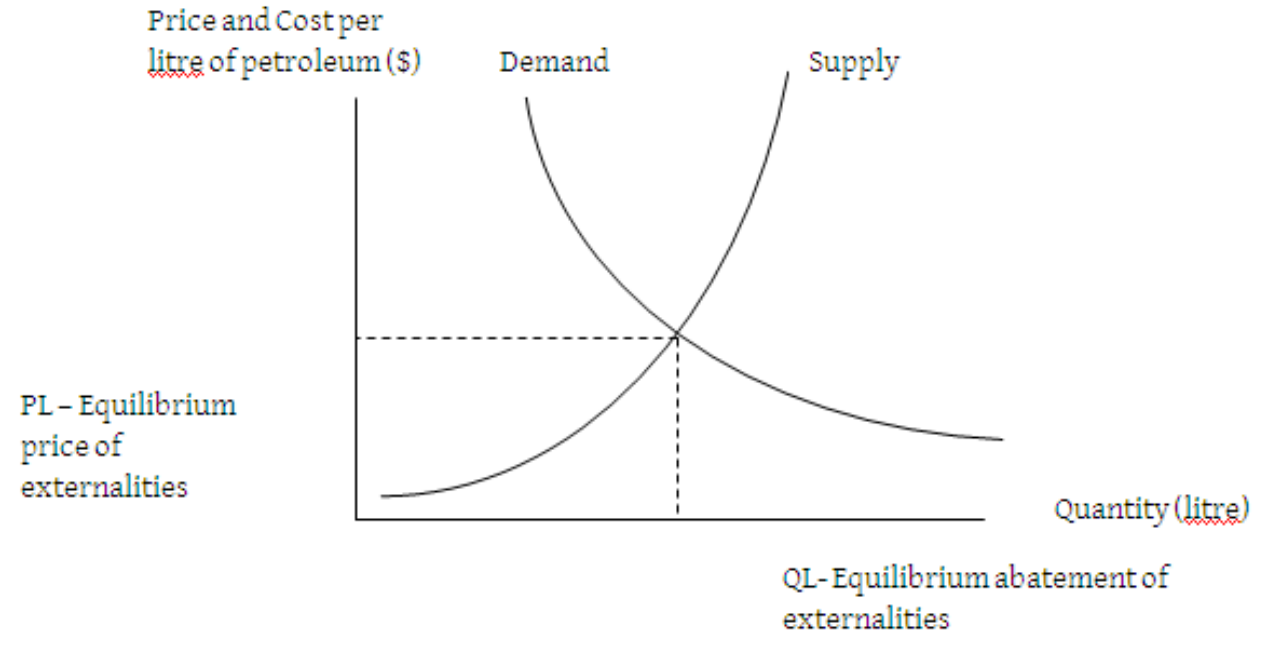

Chai et. al. 
In the short run, the change in liability rules and the creation of a Coasian market solution will reduce carbon emissions and create opportunities for new markets. These new markets may include solar and hybrid technology, which will be needed by consumers to reduce their emission levels. Furthermore, it will be possible to create new financial markets to assist in environmental preservation. The CDM helped create a private-sector finance market for environmental projects (Metcalfe \& Vorhies, 2010).

In the long run, a full-liability rule will create a higher abatement of externalities, and a reallocation of resources to control emissions. This encourages innovation to create low emission-production processes, which in turn facilitates the redistribution of income to environmental innovation sectors as well as lead to job creation. Politics and bureaucracy play a significant role in the successful implementation of a Coasian market solution. There is a danger, though, of regulatory capture by firms adversely affected by the policy outcomes entailing a Coasian solution. Hence, politicians should avoid succumbing to their own self interests.

The Coase theorem emphasizes the significant role of transaction costs. Where these are substantial, the Coasian solution does not necessarily result in efficient outcomes. Steep transaction costs will bar the achievement of solutions that are demonstrably better than the status quo. Such status quo situations can be alleviated, however, if perfect competition remains in all the industries including the transaction industry. This ensures that a Paretoefficient solution emerges i.e. all market participants shall be made better off. In order to realize this outcome, it is imperative that market participants have full information on carbon prices and that free entry is guaranteed to all firms. The production output of each firm should also be similar, and any individual firm should not be able to influence the market price of carbon.

\section{Concluding Remarks}

We conclude with the following observations on these two broad perspectives on intervention. The Pigovian tax regulation has the advantage of simplicity and cost security, 
but the high informational requirements, the lack of environmental certainty and the low price elasticity of fuel demand lessen the efficacy of this approach in curbing emissions. Furthermore, taxes are often an issue of contention for industries, consumers, and the political scene.

The Coasian market solution, on the other hand, assigns property rights to participants and creates a market for emissions trading as well as opportunities for green technology markets. The challenge is to reduce the high level of transaction costs for this approach. If transaction costs are successfully reduced, and proper institutions are in place to enforce those property rights, the Coasian market solution, in our view, would be a more attractive approach for reducing carbon emissions.

\section{References}

- Büchs, M, Duwe, S \& Bardsley, N 2009, 'Green ways of financing the welfare state?', University of Southampton, retrieved 1 September 2010, <http://eprints.soton.ac.uk/71210/1/Panel_8_Buchs_Duwe_Bardsley.pdf>.

- Engels, A 2005, Market Creation and Transnational Rule-Making: the Case of $\mathrm{CO}_{2}$ Emissions Trading, University of Hamburg, retrieved 9 September 2010, $<$ http://www.sozialwiss.unihamburg.de/onTEAM/preview/CGG/preprint/Anita_Engels_CGG_Preprint_No_2.pd f>.

- Metcalfe, J \& Vorhies, F 2010, 'Exploring the case for a green development mechanism', GDM 2010 Initial Steering Committee, retrieved 8 September 2010, <http://www.cbd.int/financial/doc/gdm-exploring-the-case-en.pdf>.

- Randall, A 1972, 'Market Solutions to Externality Problems: Theory and Practice', American Journal of Agricultural Economics, May 01, Vol. 54, No. 2, p. 175-183, retrieved 1 September 2010. 